\title{
Keeping the Genie of Licensing Out of the Bottle: Managing Inter-Dependence in Licensing Transactions
}

\author{
Jacques de Werra
}

Published online: 9 April 2014

(C) Max Planck Institute for Innovation and Competition, Munich 2014

Our globalized flat world ${ }^{1}$ tends to intensify the exchanges and interactions between the market players. It mirrors the movement of open innovation which is characterized by the increased use of third-party knowledge for the purpose of enriching a company's internal innovation (inbound open innovation), and by the continuing search of new markets and channels of distribution for the company's own innovation (outbound open innovation). ${ }^{2}$

These intensive interactions generally materialize in a multiplication of contractual relationships by which companies integrate in their products and services the intellectual assets (and intellectual property rights) of third parties, and also offer their own intellectual assets to the market according to (contractual) rules and principles that they choose. ${ }^{3}$ This makes it possible to capitalize on and benefit from the expert knowledge and experience of other market players, and can therefore contribute to an optimal allocation of corporate and societal activities and resources. These interactions can, however, generate risks that result from the reliance on the (continued) use of third-party intellectual property assets, as can be illustrated by recent court decisions rendered in various jurisdictions.

\footnotetext{
${ }^{1}$ By reference to the celebrated book of Friedman (2007).

${ }^{2}$ See the classical work of Chesbrough (2003) and his numerous subsequent publications; see http:// openinnovation.berkeley.edu.

${ }^{3}$ One avenue for fostering accessibility and sharing of opportunities is to adopt an open licensing (open content/open source) strategy. Open innovation does not necessarily mean that the knowledge that is generated is offered for free to third parties under open licensing terms. Two categories of open innovation have been identified: "open-boundary" innovation, which is designed to source new technology and concepts broadly without surrendering control of the innovation process; and "opensource" innovation, which views the source of much innovation as originating in the collective knowledge and motivation of anonymous users; see Euchner (2013).
}

J. de Werra $(\bowtie)$

Professor of Intellectual Property and of Contract Law, University of Geneva School of Law

Geneva, Switzerland

e-mail: Jacques.DeWerra@unige.ch 
In a decision of 3 December 2013, the US Court of Appeal for the Fourth Circuit affirmed a decision of the lower court which held that licensees could continue to benefit from their licenses under US patents that were granted by a foreign licensor (German-based Qimonda AG) over which insolvency proceedings had been initiated in Germany. By doing so, the US court essentially held that the interests of the licensees should prevail over those of the licensor (i.e. the German company holding the patents) thereby recognizing "that licensees have a strong interest in maintaining their right to use intellectual property following the licensor's bankruptcy" 4 and that failing to do so would "slow the pace of innovation" 5 in the United States. The Court noted that, even if the licensor (represented by the insolvency administrator in Germany) had committed to re-license the patents to the licensees on reasonable and non-discriminatory terms (RAND), this was not sufficient to eliminate the risk of dependence to which the licensees were exposed because it was "far from clear whether, having once facilitated the termination of license rights in a foreign insolvency proceeding, the genie could ever be put back into the bottle". ${ }^{6}$

Turning to Europe, the German Federal Supreme Court (Bundesgerichtshof) held in two parallel decisions rendered on the same day of July 2012 that a sublicensee could continue to benefit from its right to use the relevant work (a musical work and a software product respectively) in spite of the termination of the main license. ${ }^{7}$ The important lesson of these cases is that the termination of a main license does not necessarily affect the continuation of a sublicense.

On the other side of the Channel, the High Court of Justice (Queen's Bench Division) of England and Wales had to decide in the very first days of this year whether to grant an injunction preventing the termination of a license agreement for which the ex-licensee had applied (pending the resolution of an arbitration which had just been initiated pursuant to the arbitration clause provided for in the license agreement). The licensee claimed that its business activities totally depended on the continuation of the license agreement (which related to the use of an "eMarketplace", i.e. a commercial, Internet-based electronic platform) because the termination of the license would "permanently destroy" its business. The Court ultimately refused to grant the injunction for the reason that the licensee had failed to show that damages were not an adequate remedy, but still admitted "to a degree of unease at the result". 8

What can we learn from these decisions? Beyond the complex legal issues that they raise under the relevant applicable laws, ${ }^{9}$ these decisions fundamentally

\footnotetext{
${ }_{4}^{4}$ Jaffe v. Samsung Elecs. Co., Ltd., 737 F.3d 14, at 32 (4th Cir. 2013) (which refers to the Senate Report accompanying the Bill that became $\S 365(\mathrm{n})$ of the US Bankruptcy Code: this provision grants specific protection to licensees in case of bankruptcy of the licensor).

5 Jaffe v. Samsung Elecs. Co., Ltd., 737 F.3d 14, at 32 (4th Cir. 2013) (which quotes the expression used by the Bankruptcy Court, 462 B.R. 165, at 185 (Bankr. E.D. Va. 2011)).

${ }^{6}$ Jaffe v. Samsung Elecs. Co., Ltd., 737 F.3d 14, at 31.

7 German Federal Supreme Court, 2012 GRUR 914 - "Take Five"; ibid., 2012 GRUR 916 - "M2Trade".

8 Justice Stuart-Smith, $A B$ v. $C D(\operatorname{Rev} 2)$ [2014] EWHC 1 (QB) (3 January 2014), § 43 (in a "postscript" to the decision).

${ }^{9}$ It is not the goal of this editorial to express an opinion on these decisions under the applicable local laws; for different perspectives on licensing law, see the papers published in de Werra (2013).
} 
illustrate the growing awareness of the dependence which can be generated in intellectual property licensing transactions and which are particularly apparent and complex when these transactions have a transnational scope (as illustrated by the US decision in the Qimonda case).

They also demonstrate that courts increasingly perceive the need to protect licensees (or sublicensees) in certain circumstances, thereby reflecting the concern that licensees may sometimes be extremely (if not excessively) dependent on the use of the licensed intellectual property rights which are owned by a third party.

As we know, the entire intellectual property system is based on a balance of interests by which the existence and the scope of intellectual property rights should carefully reflect the delicate and evolving balance between the respective interests of the stakeholders (specifically the owners and the users of the rights). Now, it is also important to make sure that this balance is equally reflected in intellectual property licensing transactions. While common wisdom may hold that licensors generally benefit from a privileged position because of the control they exercise on their intellectual assets (so that, as a result, licensees depend on their licensors), the recent case law commented above suggests that licensees (and even sublicensees) have gained significant power: under certain circumstances, they can continue to benefit from a license or from a sublicense even if such possibility is not granted under the bankruptcy laws of the country where the licensor is based or even if the main license is terminated. Licensors can therefore also depend on their licensees or even their sublicensees.

Even if this is obviously good news for the licensees/sublicensees, this should not hide the fact that in a globalized world in which open innovation flourishes, almost every company is (or can quickly become) both a licensor (outbound open innovation) and a licensee (inbound open innovation). What is consequently needed is a system to manage adequately the inter-dependence between the parties to licensing transactions, and to balance equitably the respective interests of the licensees in continuing to use the licensed rights and those of the licensors in keeping control over such rights.

There should be no concern that the termination of license rights may push the genie out of the bottle. ${ }^{10}$ It is actually a good thing for the genie to come out of the bottle (it is in fact already outside). Its power should now be used in order to shape a global regime that will efficiently manage the risks of inter-dependence in licensing transactions. This is what the genie of licensing should be about.

\section{References}

Chesbrough HW (2003) Open innovation: the new imperative for creating and profiting from technology. Harvard Business School Press, Cambridge

de Werra J (ed) (2013) Research handbook on intellectual property licensing. Edward Elgar, Cheltenham. http://www.ip-licensing.info

Euchner J (2013) The uses and risks of open innovation. Res Technol Manag 56(3):49-54

Friedman TL (2007) The world is flat, 3rd edn. Picador, New York

${ }^{10}$ As reflected by the Court of the Appeal for the Fourth Circuit (supra note 6). 